In all brain injuries, bromids are given, and the patients kept at rest for some time.

Chest injuries are likewise exercised, even rib excisions being performed; and pneumothorax is closed off, foreign bodies being extracted if possible. Hemothorax is aspirated early, and cultures are made. If positive, early drainage is performed.

In the extremities, all contused and dirtied tissues - are excised down to freshly bleeding and contracting muscle, regardless of extent. Joints are approached with the greatest caution because the synovial surface may not be invaded. A painstaking careful dissection of dirtied tissues is made, and if the joint is opened or a foreign body is within, it is taken out, irrigation with neutral solution of chlorinated soda, ether, or the injection of glycerin-formaldehyd solution is made and then the joint is quickly closed off by suturing its capsule together or into the bone. The external wound is sutured or not depending on circumstances, and splint immobilization follows. I wish to impress the value of this method on surgeons entering war service. I have in preparation an article dealing with gunshots of the knee which shows plainly the great advantage of this treatment over the "leave-it-alone" or continuous irrigation treatment. All patients from castalty clearing stations are evacuated to the base as soon as they can be safely and consistently moved.

No. 12 Casualty Clearing Station, B. E. F.

\section{FIELD SANITARY ORDERS}

\section{C. MCCULI_OCH, M.D}

Culonel, Medical Corps, U. S. Army; Professor of Military Hygiene, Army Medical School

WASHINGTON, D. C.

The science and practice of military hygiene, not so many years ago, in the field at least and on a large scale, was in a somewhat unsatisfactory state. It is true that we had ideas on the subject-many of them good ones-but some very important things were not known even so recently as the Spanish-American War. For instance, our ideas were comparatively hazy as to the methods of transference of typhoid fever; we did not know that flies act as vectors, and we had but crude notions as to the effect of contact in spreading the disease. The average physician knew little about the microscopic diagnosis of malaria. Much of the typhoid fever in our army camps was erroneously called malaria-to the considerable detriment of the sanitary situation. Again, we did not appreciate the great importance of what we now call "carriers" in the propagation of infectious disease, and consequently our quarantine methods were quite imperfect.

Decided changes have, however, occurred: As the result of great improvements in laboratory and experimental methods, and the application of these to hygienic problems, we have now formed rather complete ideas as to how camp sanitation ought to be effected, at least with reference to the most important of the camp diseases. Our doctrine has been abundantly verified by the results of the practical experience of our army surgeons. Many of them, certainly those who have had considerable field experience in later years, nowadays know what to do along these lines. If we could carry out fully the scientific measures that we now know how to apply, camp diseases would no longer be serious matters. The new men will readily learn in the instruction camps, or, if they do not have the benefit of these, soon after seeing active service with the troops, all the important points, most of them quite simple, as to what can and should be done in field sanitation.

The real issue of importance nowadays in military sanitation is whether those things that we know how to do and that can readily be done will actually be put into practice. This, in turn, depends almost entirely on whether the sanitary officer can obtain the cooperation of the line officers and soldiers. Everything in the army comes back in the end to the question of rank and command. I think that, without doubt, the most satisfactory-indeed, the only sure way-is to induce the commanding officer to issue a general sanitary order in the beginning, signed by his authority, and explaining in a general way the sanitary duties of the command, and the methods prescribed for their accomplishment. This persuasion ought not, in these times, to be very difficult. Laymen are coming more and more to realize that something must be done in the way of sanitation. Having issued this order himself, the commander will continue to support it, especially after he sees the results, including much benefit to his own peace of mind, that accrue from the plan.

The real secret of success in military sanitationthe key to practical results along these lines-is the sanitary order. I think the idea important enough, at least, to be exploited for the benefit of the many civilian physicians now in army service. A minor benefit accruing from the order is the avoidance of differences among medical officers themselves as to the sanitary measures advised in their several organizations. These might all be good and yet conflict with each other when it comes to the question of administration.

We have always had some notion in the Army as to sanitary orders and their value; but the first time that the idea was worked out in detail in a camp of large dimensions, and used in a practical way, was at the divisional maneuver camp at San Antonio, Texas, in 1911. This was, indeed, the first camp on a large scale, of which we have record in our Army, in which the sanitary arrangements and results may be said to have been entirely satisfactory. There was no serious disease-very little of any kind-thus affording a most striking contrast with our Spanish War camps of a few years before. The occasion was, indeed, an epochmaking one for field sanitation. The main point is that the remarkable sanitary results attained there coincided with the fact stated above, namely, that this was the first occasion of the issue and use as a working basis of the divisional sanitary order. We had the antityphoid vaccination, it is true; we had many improved sanitary methods; but that these really proved effective was no doubt largely due to the order. It was issued by Major-Gen. W. H. Carter, under advice of Col. H. P. Birmingham, division surgeon, and Major P. F. Straub, sanitary inspector. The experience was repeated, and entirely adequate sanitary results were attained in the division camp at Galveston, Texas, a few years later. Major-General Carter was again in command. Col. W. B. Banister was division surgeon, and Major R. B. Miller, sanitary inspector.

The following model for a divisional sanitary order, which shows about what we should aim at, is based on the San Antonio order, and is constructed in accordance with the form recommended by Straub. ${ }^{1}$

1. Straub, P. F.: Sanitation of the Maneuver Camp at San Antonio, Texas, Mil. Surgeon, 1911, 29, 607. 
MODEL FOR DIVISIONAL SANITARY ORDER Headquarters, Nth Infantry Division, (Place)

General Orders, (Date)

The following regulations for field sanitation are published for the guidance of all concerned:

1. Drvision Surgeon.-The division surgeon is charged, uinder the commanding general, with the general conduct and supervision of the Medical Department of the division, and will make timely recommendation concerning all matters pertaining to the sanitary welfare of the command.

2. SANITARY INSPECTOR.-The division sanitary inspector is charged, under the division surgeon, with investigating and reporting on the sanitation of the command. He will report the results of his inspections to local commanders as well as to the division surgeon. Commanders of all grades are responsible for the sanitary condition of the localities occupied by their commands and for the enforcement of sanitary regulations within their organizations.

3. Regimental Surgeons.-The senior medical officer of each regiment or other organization will make at least one inspection daily of his command, and report orally any sanitary defects, with proper recommendations for the correction of the same, to his immediate commanding officer, who will immediately take the necessary steps for their correction, if within his authority. If beyond his facilities, or if considered impracticable, he will immediately report the facts, with full explanation, for action of higher authority.

4. Water Supply.-All drinking water supplies will be disinfected by the hypochlorite process in the field sterilizing water bag. To prevent subsequent contamination, containers must be kept scrupulously clean and protected from dust and other sources of infection.

5. Disposal of Waste.-Defilement of the ground in or about the camp is absolutely prohibited, and organization commanders will be held strictly responsible for the sanitary police of their respective camps. (a) Human Excreta.Human excreta will be disposed of in pits provided with latrine boxes; urine by day in urine soakage pits, and at night by urinal cans placed in the company streets. Pits and cans will be burned out with crude oil and hay, and seats scrubbed with cresol solution, daily. It must be remembered that fly-proofing is the essential end aimed at in these waste disposal measures. (b) Kitchen Wastes.-Each company or other organization will construct and use exclusively rock pile incinerators for the disposal of all solid and liquid garbage. Garbage cans must be kept scrupulously clean. For the general waste of the camp areas not under the jurisdiction of subordinate commanders, rock pile crematories will he erected and used under the direction of the regimental sanitary squad. No bath or other waste water collections that might breed mosquitoes will be allowed. (c) Picket Line Wastes.-Picket lines will be gone over daily, and all manure and sweepings collected and hauled to the designated dumping ground, where they will be burned in incinerators. The picket lines will be burned over weekly with crude oil.

6. FOOD AND DRINK.-No articles of food or drink will be sold in camp, except in the authorized exchanges, and no purchases of such articles made by soldiers, outside of camp cxcept from properly licensed venders. Company kitchens and mess rooms will be securely screened, or such additional or alternative method instituted, acceptable to the division surgeon, as will prevent access of flies and dust to food or its containers.

7. Tent Hygiene.-Organization commanders are directed to assure themselves personally that suitable ventilation of tents and sunning of tent areas are practiced by their men; as also, adequate personal cleanliness. Mosquito bars and head nets and prophylactic quinin will be used when directed by competent medical authority.

8. Quarantine.-All regulations imposed by competent medical authority as to isolation in the case of infectious disease, or prophylactic measures in regard to the same, will be scrupulously observed by the command.
9. Sanitary Squads.-Sanitary squads will be organized by the division surgeon for each regiment, or other organization. One of the regimental medical officers will act as local sanitary police officer. He will be assisted by a Hospital Corps sergeant and the requisite number of Hospital Corps privates and civilian laborers. These squads will do wholetime work, and will supervise and assist in the purification of drinking water, the disposal of camp wastes, and in disinfection. A general sanitary squad, under a divisional sanitary police officer, will also be organized for sanitary work not pertaining to organizations, such as the handling of manure, general drainage, antimalarial work, the final police of vacated grounds, etc. Civilian sanitary laborers will be employed by the Quartermaster Corps and turned over to the Medical Department. The sanitary police officers will make requisition on the chief quartermaster for such transportation, labor or material as may be needed for sanitary work; when assigned to this service, they will not be diverted to other uses except by orders from these headquarters.

By Command of Major-General Blank:

OfFICIAL. A. B. C.,

X. Y. Z., Chief of Staff.

Adjutant-General.

\section{COMMENT}

The foregoing order, as stated, follows Straub's outline, which is the best for practical purposes. In Sections 4 and 5, certain suppositions are made for clearness' sake, as to the water supply and the methods employed for the disposal of excreta. Of course, in some camps, the water supply might be piped from a pure source, and disinfection would not be necessary; or, again, the incineration method might be used for the disposal of excreta. In such cases, the order could easily be modified to correspond with the local situation. In most other respects, the order, as written, would apply in any situation. The order can also, when necessary, be easily changed to apply to a brigade or regimental or even smaller camp. In any case, however, an order should issue.

Field orders should not go into too much detail as to methods; merely the authority and a general statement as to the kind of methods to be employed are wanted. The details are described from time to time in circulars published by the Surgeon-General's Office or the War Department. The order, in other words, is not intended as a sanitary text, but merely as a sanitary authority. Directness and conciseness are necessarily the chief desiderata in military orders.

The model suggested is perhaps a little too long, but by making it long I have been able to include by mention, or at least by inference, practically all the subjects to which the neophyte in field sanitation would be likely to have his attention at first directed. It is hoped that a careful perusal of the order will clear up what at first seems a rather difficult matter, and afford an easy and satisfactory means of orientation at this period for the new medical officer in the work of cultivating "preparedness" for his service in actual campaign.

The medical officer should never forget that results are what the nation demands. They must be produced. The way for the medical officer to secure them is to establish a satisfactory working relation with line officers, who alone have the power, and on whose action the successful or unsuccessful issue of the sanitary as well as of the military situation must in the final analysis really depend.

Army Medical Museum, Seventh and B Streets S.W. 